\title{
CLIMATIC ASPECTS RELATED TO THE DISTRIBUTION OF BRAZILIAN PINE IN THE STATE OF SANTA CATARINA
}

\author{
Elenice Fritzsons ${ }^{1^{*}}$, Marcos Silveira Wrege ${ }^{2}$, Luiz Eduardo Mantovani ${ }^{3}$ \\ ${ }^{1 *}$ Embrapa Forestry, Reasercher on Climatic Zoning and Water Monitoring Areas - elenice.fritzsons@embrapa.br \\ ${ }^{2}$ Embrapa Forestry, Researcher on Agrometeorology - marcos.wrege@embrapa.br \\ ${ }^{3}$ Federal University of Paraná, PhD, Departament of Geology - lem@ufpr.br \\ Received for publication: 15/06/2017 - Accepted for publication: 14/05/2018
}

\begin{abstract}
The natural presence of Araucaria angustifolia (Bert) O. Kuntze is associated with several climatic aspects, but the relative importance of each of them has not been sufficiently explored yet. The objective of this study was to identify climatic aspects that are most related to the presence of the species in the state of Santa Catarina, Brazil. For this purpose, meteorological stations from the municipalities were separated into: places with records of natural occurrence of araucaria; and places without records of the species. Temperature, precipitation and insolation data from these stations were employed, and they were subjected to several univariate and multivariate statistical tests to identify the climates in which araucaria preferentially develop. All the areas presented surplus water, and the insolation hours did not present significant differences. The areas where the araucaria occurred were also separated into three subgroups: two in the Southern Plateau; and one in the highest western sides of the state. These areas were climatically different regarding precipitation, evapotranspiration, and water availability. Finally, we concluded that the araucaria occurs in places where the average temperatures are lower and the annual rainfall and the winter period rainfall are higher. The results generated by cluster analysis indicated the prospection conditions for in situ conservation purposes. Also, it would assist in the elaboration of breeding programs.

Keywords: Mixed Ombrophilous Forest, genetic conservation, ecological niche, native species.
\end{abstract}

\section{Resumo}

Aspectos climáticos relacionados à distribuição do pinheiro-do-paraná no estado de Santa Catarina. A presença natural de Araucaria angustifolia (Bert) O. Kuntze está associada a várias características climáticas, porém a importância relativa de cada uma delas ainda não foi suficientemente explorada. O objetivo deste trabalho foi identificar os aspectos climáticos mais fortemente relacionados à presença da espécie no estado de Santa Catarina. Para isso, foram separadas as estações meteorológicas dos municípios com registros de ocorrência natural da araucária e os sem registro de ocorrência. A partir dessas estações, foram utilizados os dados de temperatura, precipitação e insolação, os quais foram submetidos a testes estatísticos uni e multivariados para identificação do clima em que a espécie se desenvolve preferencialmente. Em todas as áreas, houve excedente de disponibilidade hídrica. As áreas com e sem araucária não apresentaram diferenças quanto à insolação. Foram separadas três regiões de ocorrência natural: duas no Planalto Meridional e uma no Oeste do estado, nas regiões de maiores altitudes. Essas áreas eram climaticamente diferentes quanto à precipitação, evapotranspiração e disponibilidade hídrica. Concluiu-se que, em Santa Catarina, a araucária ocorre, preferencialmente, em locais onde as temperaturas médias são menores e as precipitações, tanto anuais quanto do período de inverno, são maiores. Os conhecimentos gerados pela análise de agrupamento indicaram, previamente, áreas distintas de prospecção para fins de conservação in situ, auxiliando também na elaboração de programas de melhoramento genético.

Palavras chave: Floresta Ombrófila Mista, conservação genética, nicho ecológico, espécies nativas.

\section{INTRODUCTION}

Throughout the 19th century, the Araucaria Forests with all of its associated species, also known as the Ombrophylous Mixed Forest (FOM), comprised about 35\% of the vegetation cover of the Southern Brazilian states, spreading through the states of Paraná $(40 \%)$, Santa Catarina $(31 \%)$ and Rio Grande do Sul $(25 \%)$. Northward from the Southern region of the state of São Paulo, this typology became naturally fragmented, appearing in refuges in the highest areas of the Serra do Mar (Costal mountais) and the Serra da Mantiqueira (Mantiqueira Mountains), Southeast of São Paulo, and South of Minas Gerais, Rio de Janeiro and Espírito Santo. Currently, the FOM is considered one of the most threatened ecosystems in Brazil (KLEIN, 1972) and, acccording to some estimates, only 3\% (BAUERMANN; BEHLING, 2009) (primary forest) to 13\% (RIBEIRO et al., 2009) (secondary forest) of its original coverage still exists.

FLORESTA, Curitiba, PR, v. 48, n. 4, p. 503-512, out/dez. 2018

Fritzsons. E. et.al.

ISSN eletrônico 1982-4688

DOI: $10.5380 /$ rf.v48i4.53272 
This reduction in area resulted from logging activitites, removal of vegetation to enable agriculture and cattle industry efforts and expansion of urban areas from the Twentieth Century onwards. It is estimated that the remaining forest does not represent more than $0.7 \%$ of the original coverage (MEDEIROS et al., 2005). As this area declined by at least $80 \%$ in 80 years, the araucaria could now be considered as in danger of extinction and classified as "Critically endangered" (CR), although the "Red Book of Brazilian Flora" still establishes its status as "Endangered" (EN). This occurs because the araucaria is found in full Protection Conservation Units (UC) and has a high cultivation potential (MARTINELLI; MORAES, 2013).

According to Arzolla et al. (2014), during the Quaternary Period of the Pleistocene, a geological time that begun 2,595 million years ago, as the climate was cooler, the latitudes and altitudes in which the araucaria was found were lower than the current ones. Then, 11,700 years ago, as the climate became warmer and more humid in the Holocene, the Dense Ombrophylous Forest and the Semideciduous Seasonal Forest outgrew the Ombrophylous Mixed Forest. The disjointed distribution of forests in higher or cooler regions is evidence of a wider distribution in the past and of its subsequent regression under the current climate.

The Ombrophylous Mixed Forest is considered a forest typical of the Southern Brazilian and the Atlantic Forest Biome and one of the forest most sensitive to climatic variations (KLEIN, 1972). Currently, the FOM is present in a wide range of environmental, geological, pedological, geomorphological and climatic conditions. The geographical distribution of the araucaria and the FOM is determined by the climatic conditions, since they are adapted to regions that register lower temperatures and frost occurrence. Therefore, more prominent than the soil, the climate is a conditioning factor in the establishment of the araucaria (PUCHALSKI et al., 2006). According to Puchalski et al., average annual temperatures higher than those registered in the natural range intefere with the reproductive cycle, preventing the species' natural regeneration and establishment. In this regard, it should be noted that in warmer climates (Cfa) there are no natural populations of araucaria, whereas in warm climates the thriving species are those that show a greater regeneration capacity and a more vigorous growth.

Currently, climate risk poses a new threat to the existence of both the FOM and the Araucaria angustifolia, as global warming may lead to the extinction of these species in the border and push them to regions of even greater altitude and lower temperature. These higher regions are characterized by mild climate and high humidity (CHOU et al., 2014; NAVAS CRUZ-NETO, 2008), in addition other limiting edaphoclimatic conditions. Furthermore, the loss of native ecosystems may also modify the surface climate's local and regional relationship through a feedback process and increase the risks imposed by extreme climates (GRIMM; TEDESCHI, 2009).

For long-lived species such as forest species, the adaptation process should be slower than the evolution of climate changes. Therefore, the understanding of the araucaria's natural range climatic distinctions and characteristics, all of which enable its development, may help to design strategies aimed at preserving in situ and improving the species for forest purposes, in addition to providing its actual and future management. Accordingly, the goal of this study was to identify the climatic aspects more closely related to the natural presence of the araucaria and the different climatic clusters that occur in the state of Santa Catarina.

\section{MATERIAL AND METHODS}

The state of Santa Catarina is located in Southern Brazil. It has an area of 95,483 $\mathrm{km}^{2}$ and more than $502 \mathrm{~km}^{2}$ of territorial waters, totaling $95,985 \mathrm{~km}^{2}$, which corresponds to $1.12 \%$ of the Brazilian territory and $16.6 \%$ of the Southern area (PANDOLFO et al., 2002). Santa Catarina has distinct landscapes characterized by a marked climatic diversity, geological formations, geomorphological compartmentalisation, toposequences, pedological associations and land use and occupation. Its climate is the moist mesothermal $\mathrm{Cf}$, which includes the subtypes $\mathrm{Cfa}$ and $\mathrm{Cfb}$ (Köppen classification). The $\mathrm{Cfa}$ is the prevailing climate in the Atlantic coast, while the $\mathrm{Cfb}$ predominates in the Plateau (WREGE et al., 2011; PANDOLFO et al., 2002).

This study examined climatic data collected by the network of meteorological stations operated by the Company of Agricultural Research and Rural Extension of Santa Catarina (CIRAM / Epagri), according to Wrege et al. (2011). The meteorological stations were divided in two clusters according to their ability to enable the development of the A. angustifolia: areas with climatic conditions that allowed the development of the araucaria and areas where the araucaria did not occur or where its cultivation was not recommended. In order to determine which areas had the conditions that allowed the development of the araucaria, the study analyzed the Ecological Zoning for Forest Planting of the State of Santa Catarina (CARPANEZZI; CARVALHO, 1988). It also verified satellite images from Google Earth depicting the area within a 1,000 m radius of each meteorological station, using the most recent pictures available for each area.

The following climatic data were used in this study: average annual temperatures $\left({ }^{\circ} \mathrm{C}\right)$; average annual summer temperature (January, February and March); average winter temperature (June, July and August); total average annual rainfall $(\mathrm{mm})$; total winter precipitation $(\mathrm{mm})$; total summer precipitation $(\mathrm{mm})$; difference 
between summer and winter precipitation and evapotranspiration $(\mathrm{mm})$; altitude $(\mathrm{m})$; and annual average sunshine (hours). The data was obtained from the network of meteorological stations operating in Southern Brazil and analyzed, completed and corrected by Wrege et al. (2011). The study covered the period between 1976 and 2005. The data was organized in computer spreadsheets and submitted to descriptive statistical analysis that determined the clusters average, maximum and minimum values. The T test (Student's test) was applied to verify which climatic variables were significantly different between the average values of the two groups (with and without araucaria). As the data was continuous, the Mann Whitney test to compare medians was also applied.

For the variables rainfall, water availability and altitude, samples were taken from 58 sites with araucaria and 58 without araucaria; for insolation, 17 sites with araucaria and 13 without araucaria; and for temperature, 24 sites with araucaria and 18 without araucaria, according to the data available.

A cluster analysis was performed with the data obtained from the meteorological stations where araucaria planting was recommended or where the species occurred in its natural range. For this analysis, the data gathered by all stations was used: rainfall; potential evapotranspiration; water availability (P-ETP) and altitude. The grouping analysis enables the study of the interdependence relations between a set of interdependent variables allows the grouping of elements according to their similarities and proximities based on this set of variables (HAIR et al., 2009). Consequently, the elements in each cluster tend to be similar to each other and different from the elements in other clusters.

The ANOVA was applied to differentiate the subgroups identified through the cluster analysis, and the frequency distribution charts indicated those differences. The analysis of variance is a parametric test equivalent to the $\mathrm{t}$ test (applied to two groups) and compares the averages of three or more groups. Applying the ANOVA to independent groups requires performing an analysis of the independence assumptions related to the observations, normality and homogeneity of variances.

\section{RESULTS}

\section{Comparing groups with or without araucaria}

The values obtained in the t-test and the Mann Whitney test (Table 1) confirmed that the probability of the two clusters (with and without araucaria) means and medians being equal was lower than 0.05 considering almost all of the climatic parameters analyzed. Therefore, the two clusters are different. The exceptions were the summer water availability and the (summer and winter annual) sunshine hours, which were similar for both groups.

Table 1. T-test and Mann Whitney test results and their respective $p$ values for the parameters analyzed in clusters with climatic suitability for araucaria (GCA) and without climatic suitability for araucaria (GSA).

Tabela 1. Testes t e Mann Whitney, com os respectivos valores p para os parâmetros analisados nos grupos com aptidão climática para araucária (GCA) e sem aptidão climática para araucária (GSA).

\begin{tabular}{|c|c|c|c|c|c|c|}
\hline Variables & T-test & P Value & $\begin{array}{c}\text { Mann } \\
\text { Whitney }\end{array}$ & P Value & $\begin{array}{l}\text { GSA Average } \\
\text { Value } \\
\end{array}$ & $\begin{array}{c}\text { GCA Average } \\
\text { Value } \\
\end{array}$ \\
\hline Altitude (m) & -17.601 & $0 *$ & 3276 & $0 *$ & 176 & 895 \\
\hline $\begin{array}{l}\text { Average annual } \\
\text { temperature }\left({ }^{\circ} \mathrm{C}\right)\end{array}$ & 7.381 & $4.81 \mathrm{E}-09 *$ & 35 & $0 *$ & 19.7 & 16.5 \\
\hline Sumer temperature $\left({ }^{\circ} \mathrm{C}\right)$ & 6.178 & $7.42 \mathrm{E}-07 *$ & 45.5 & $0 *$ & 23.5 & 20.4 \\
\hline Winter temperature $\left({ }^{\circ} \mathrm{C}\right)$ & 7.754 & $1.45 \mathrm{E}-09 *$ & 28.5 & $0.00 *$ & 15.4 & 12,5 \\
\hline Average July temperature & & & & & & \\
\hline $\begin{array}{c}\left({ }^{\circ} \mathrm{C}\right) \\
\text { Average January }\end{array}$ & 9.216 & $0 *$ & 10 & $1.26 \mathrm{E}-7 *$ & 14.9 & 11,9 \\
\hline temperature $\left({ }^{\circ} \mathrm{C}\right)$ & 7.129 & $0 *$ & 27.5 & $0 *$ & 24 & 21 \\
\hline $\begin{array}{l}\text { Total annual precipitation } \\
\qquad(\mathrm{mm})\end{array}$ & -2.524 & $0.0129 *$ & 2218 & $0.00212 *$ & 1659 & 1767 \\
\hline $\begin{array}{c}\text { Summer precipitation } \\
(\mathrm{mm})\end{array}$ & 2.436 & $0.0164 *$ & 1223 & $0.014468 *$ & 551 & 507 \\
\hline $\begin{array}{c}\text { Winter precipitation } \\
(\mathrm{mm})\end{array}$ & -10.643 & $0 *$ & 3093 & $0 *$ & 314 & 407 \\
\hline $\begin{array}{l}\text { Annual water availability } \\
\qquad(\mathrm{mm})\end{array}$ & -5.757 & $0 *$ & 2703 & $0 *$ & 746 & 975 \\
\hline $\begin{array}{c}\text { Summer water } \\
\text { availability }(\mathrm{mm})\end{array}$ & -0.376 & 0.7075 & 1720 & 0.7579 & 201 & 208 \\
\hline $\begin{array}{l}\text { Winter water availability } \\
\qquad(\mathrm{mm})\end{array}$ & -11.750 & $0 *$ & 3093 & $0 *$ & 192 & 296 \\
\hline Evaporation (mm) & 11.41 & $0 *$ & 222 & $0 *$ & 913 & 792 \\
\hline
\end{tabular}

FLORESTA, Curitiba, PR, v. 48, n. 4, p. 503-512, out/dez. 2018

Fritzsons. E. et.al.

ISSN eletrônico 1982-4688

DOI: $10.5380 /$ rf.v48i4.53272 


\begin{tabular}{ccccccc}
\hline $\begin{array}{c}\text { Summer evaporation } \\
\text { (mm) }\end{array}$ & 11.85 & $0 *$ & 206 & $0 *$ & 350 & 298 \\
Winter evaporation (mm) & 9.59 & $0 *$ & 359 & $0 *$ & 123 & 110 \\
Total annual sunshine & & & & & & 154 \\
(hours) & -1.550 & 0.1322 & 136.5 & 0.3183 & 167 & 186 \\
Summer sunshine (hours) & -0.188 & 0.070 & 156 & 0.10488 & 153 & 157 \\
Winter sunshine (hours) & -0.333 & 0.7413 & 150 & 0.1239 & 153
\end{tabular}

In which: *: significantly different; GSA: Group Without Araucaria; and GCA: means Group With Araucaria.

The temperature values recorded were significantly lower in the regions favorable to the development of araucaria. The cumulative annual rainfall and the cumulative winter rainfall were higher in areas with araucaria while cumulative summer precipitation was higher in areas without araucaria.

The summer and winter cumulative annual potential evapotranspiration was higher in regions without araucaria and the difference between precipitation and potential evapotranspiration (P-ETP) was higher in areas with araucaria. This was verified mainly in winter, as the difference was not significant in summer.

The altitude was also tested due to its direct relation with temperature. In this regard, there were significant differences between the two clusters, and the areas with araucaria registered larger differences.

The cluster analysis of the regions with araucaria generated the dendrogram shown in Figure 1. The regions were divided into two clusters (A and B) and then further divided into A1, A2 and B1.

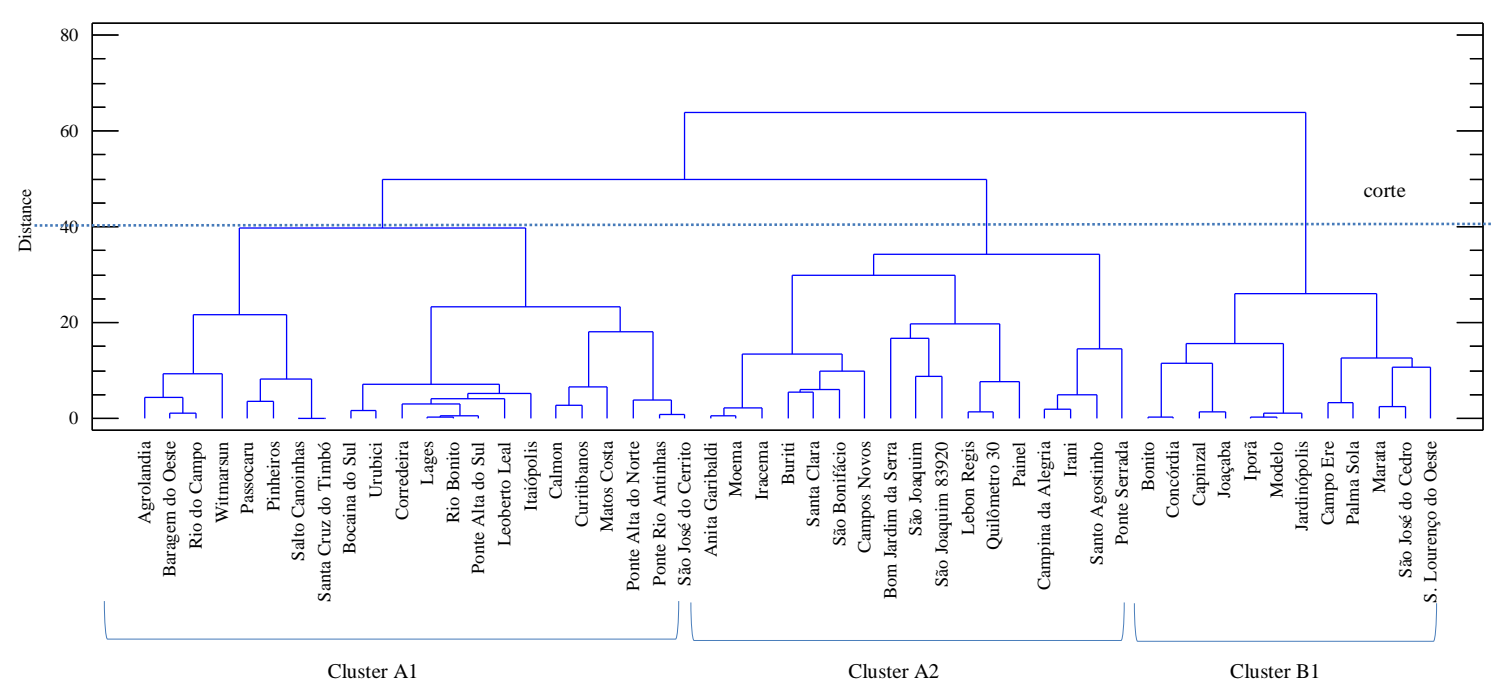

Figure 1. Cluster analysis dendrogram covering the areas with araucaria in the state of Santa Catarina.

Figura 1. Dendrograma da análise de agrupamento dos municípios com araucária no estado de Santa Catarina.

Groups A1 and A2 occurred predominantly in the mountainous and Northern regions of Santa Catarina while the B1 group was identified at the Western portion of the state (Figure 2). 


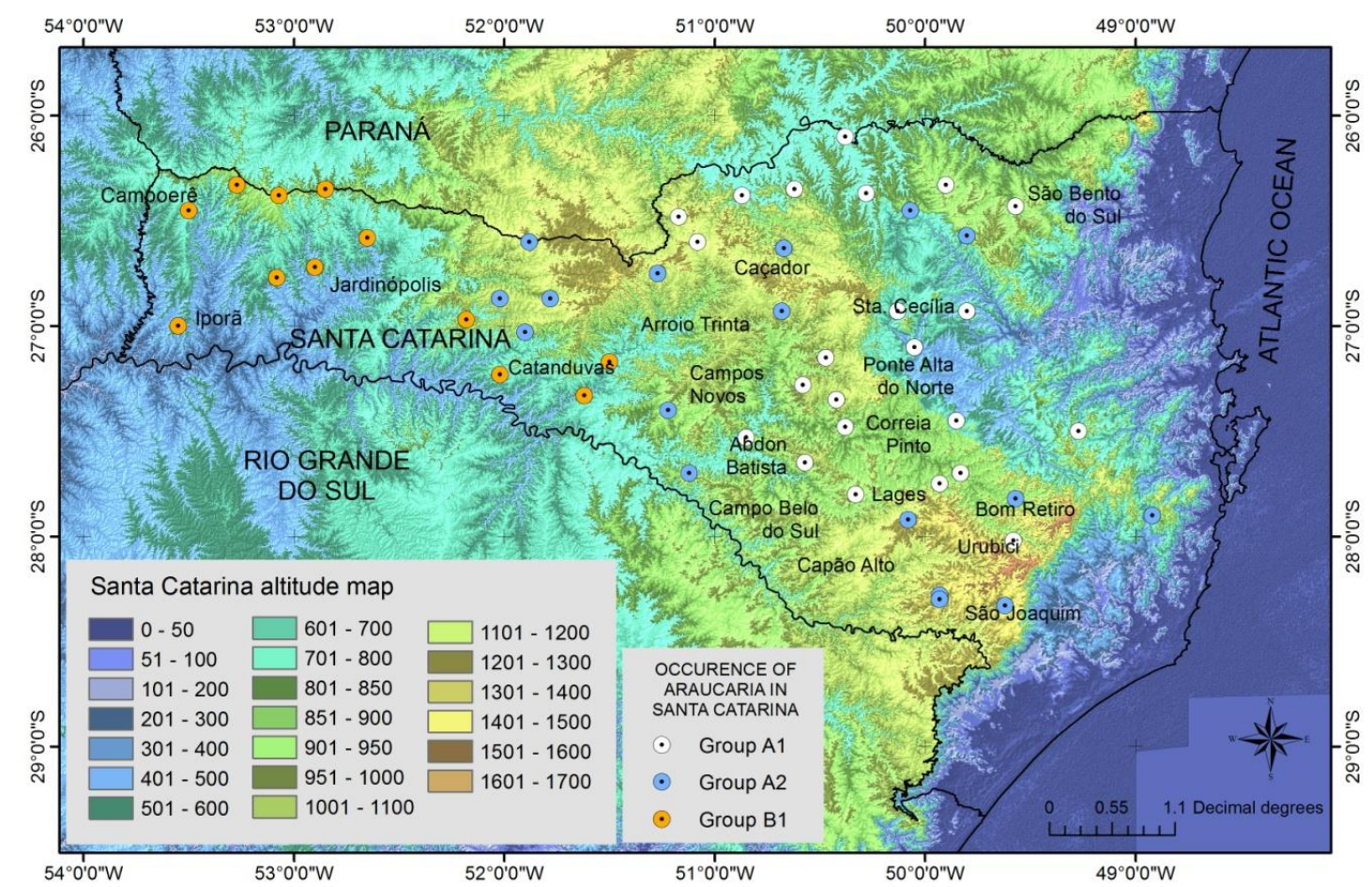

Figure 2. Clusters of regions with araucaria in the State of Santa Catarina.

Figura 2. Grupos das regiões com presença de araucária em Santa Catarina.

\section{Climatic differentiation of areas with araucaria in the state of Santa Catarina}

The ANOVA applied to the groups (A1, A2 and B1) showed significant differences in the following variables: total annual rainfall; total annual potential evapotranspiration; water availability and altitude (Table 2)

Table 2. ANOVA and the group parameters analyzed.

Tabela 2. ANOVA, com os parâmetros analisados para os grupos.

\begin{tabular}{cccccc} 
Variables & \multirow{2}{*}{ F Test } & P Value & \multicolumn{3}{c}{ Groups (average values) } \\
& & & A1 & A2 & B1 \\
\hline Precipitation $(\mathrm{mm})$ & 40.27 & 0.0000 & $1607^{\mathrm{a}}$ & $1819^{\mathrm{b}}$ & $1999^{\mathrm{c}}$ \\
Evapotranspiration $(\mathrm{mm})$ & 41.74 & 0.0000 & $817^{\mathrm{a}}$ & $1085^{\mathrm{b}}$ & $1122^{\mathrm{b}}$ \\
Water availability (mm) & 34.29 & 0.0000 & $791^{\mathrm{a}}$ & $734^{\mathrm{b}}$ & $877^{\mathrm{c}}$ \\
Altitude (m) & 22.43 & 0.0000 & $856^{\mathrm{a}}$ & $1104^{\mathrm{b}}$ & $672^{\mathrm{c}}$ \\
\hline
\end{tabular}

The group B1 had higher rainfall, water availability and evapotranspiration. This last variable was not significantly different from the group A2. Located in the Santa Catarina Plateau, the group A2 had the highest altitudes, whereas the lowest terrain was identified in the group B1, located in the Westhern portion of the State, as shown in the Boxplot chart (Figure 3). This chart demonstrates clearly the data distributed in quartiles and underlines the mean and atypical values. The boxes have horizontal lines ("whiskers") that indicate the variability outside the upper and lower quartiles, and all points outside these "whiskers" are considered atypical values.

FLORESTA, Curitiba, PR, v. 48, n. 4, p. 503-512, out/dez. 2018

Fritzsons. E. et.al.

ISSN eletrônico 1982-4688

DOI: $10.5380 /$ rf.v48i4.53272 


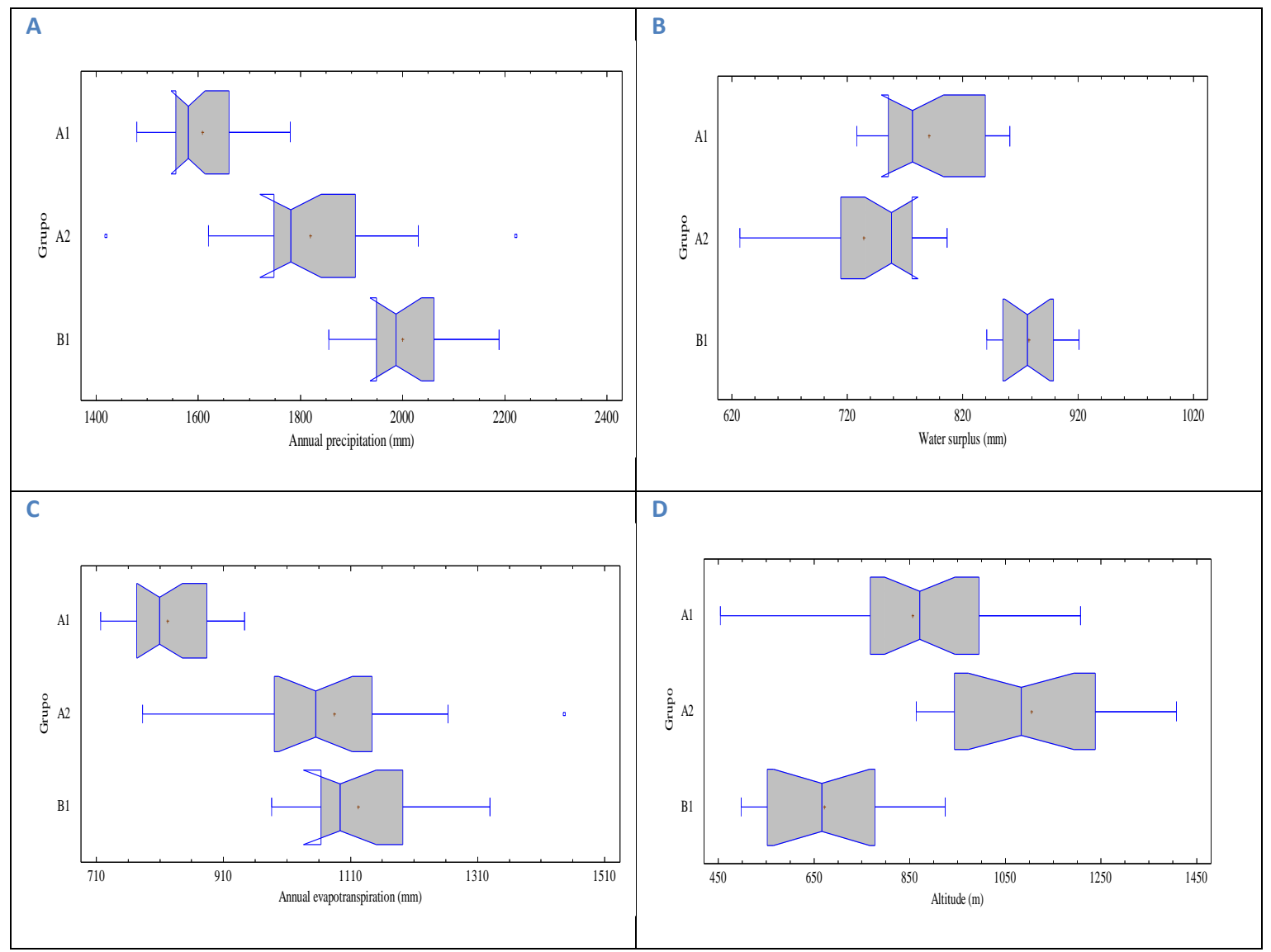

Figure 3. Box and Whisker Plot chart showing the total annual precipitation (A), water surplus (B), total annual evapotranspiration (C) and altitude (D) observed in the groups A1, A2, and B1.

Figura 3. Gráfico boxplot para total de precipitação pluvial anual (A), total de evapotranspiração potencial anual (B), excedente hídrico (C) e altitude (D) para os grupos A1, A2 e B1.

\section{DISCUSSION}

\section{Climatic differentiation of areas with and without araucaria in the State of Santa Catarina}

The Central and Western portions of the state of Santa Catarina offer the most favorable climatic conditions for the occurrence of araucaria. Descending from the Serra do Mar (Santa Catarina Mountains), the state's Atlantic slope is very hot and humid, especially in the summer, enabling the development of other forest formations, such as non-coniferous species more vigorous than the araucaria. According to Klein (1972), the high rainfall of the region rate produces humidity very close to that of the equatorial forests (such as Amazonian forests).

The natural range of the Araucaria Forest is determined by a temperate climate, high rainfall, frequent frosts and the $18{ }^{\circ} \mathrm{C}$ isotherm (BACKES, 1999). That is, the araucaria occurs in regions where the average annual temperature is lower than $18{ }^{\circ} \mathrm{C}$, as stated in the results of this study $\left(16.5^{\circ} \mathrm{C}\right)$. The monthly average may be lower than $10{ }^{\circ} \mathrm{C}$ in colder period and higher than $20^{\circ} \mathrm{C}$ in warmer period (BACKES, 1999). For this study, the monthly average recorded in the regions with araucaria was of $11.9^{\circ} \mathrm{C}$ in July (the coldest month) and $21{ }^{\circ} \mathrm{C}$ in January (the hottest month).

Based on the data analyzed in this study and the elevation of the meteorological network stations, it was observed that the altitude of the regions favorable to the development of the araucaria ranged between $454 \mathrm{~m}$ in the city of Agrolândia (in the micro-region of Rio do Sul) and 1,407 m in the city of São Joaquim. The regions without A. angustifolia went from sea level, in the Santa Catarina coast, to $684 \mathrm{~m}$ in the city of Benedito Novo (in the micro-region of Blumenau, meso-region of Vale do Itajaí).

According to Maack (1981), the continuous distribution of the araucaria ceases at an altitude of $500 \mathrm{~m}$ in the states of Paraná and Santa Catarina. Below this line, the species occurs only discontinuously, following the cold air currents. As stated by Roderjan et al. (2002), the araucaria appears in areas with altitude ranging between 650 and $700 \mathrm{~m}$ in Paraná and 750 and 800 in São Paulo. Thus, this lower latitude compensated by a higher altitude accounts for the presence of the araucaria at lower altitudes in Santa Catarina in relation to the state of São Paulo. 
Temperature varies with altitude and latitude and usually decreases with elevation by a ratio of approximately $1{ }^{\circ} \mathrm{C} / 100 \mathrm{~m}$ (adiabatic gradient of dry air) (VAREJ ÃO-SILVA, 2006). In the state of Paraná, Maack (1981) sets this ratio at $0.5^{\circ} \mathrm{C} / 100 \mathrm{~m}$. In a study examining the state of Santa Catarina, Fritzsons et al. (2016) found a decrease of $1{ }^{\circ} \mathrm{C}$ per 213 meters of vertical ascent or $0.47{ }^{\circ} \mathrm{C} / 100 \mathrm{~m}$. This value was determined using a regression line with coefficient of determination of $0.85 \%$. The altitude was the most influential factor regarding temperature, followed successively by latitude and longitude. The average annual temperature showed a difference ranging between $1.08{ }^{\circ} \mathrm{C}$ and $1.30{ }^{\circ} \mathrm{C}$ per degree of latitude and between $0.18{ }^{\circ} \mathrm{C}$ and $0.62{ }^{\circ} \mathrm{C}$ per degree of longitude, increasing westwards.

Therefore, the lowest temperatures registered in each season make possible the existence of the araucarias, since the species is less competitive than more adapted plants in warmer locations. In addition to its lack of competitiveness in these settings, the growth of the araucaria relies on higher rainfall rates associated with lower temperatures. Furthermore, there is a close link between a large water supply and the growth of the araucaria in regions without annual water deficits. However, this issue deserves further inquiry, since Zanon and Finge (2010) found that precipitation accompanied by very low temperatures affects the species' girth, in a study carried out in São Francisco de Paula, a city in the Northeastern ridge of the state of Rio Grande do Sul. São Francisco de Paula offers much colder and more humid conditions and has an average winter temperature of $11.8^{\circ} \mathrm{C}$ (WREGE et al., 2016).

In addition to determining the precipitation, the study calculated the evapotranspiration and the difference between these two values, which indirectly establishes the site's water availability without taking into account its ground water storage capacity. Especially in the winter, a greater water supply (precipitation minus evapotranspiration) was identified in areas with araucaria.

There is no dry season in Santa Catarina. The state is located in a subtropical zone under the influence of several atmospheric circulation patterns, receiving both Atlantic moisture flows from the eastern quadrant and low-pressure moist currents from the northwest quadrant (from the Amazon) and from the eastern quadrant (from the Atlantic). Coming from the South and Southwest quadrants, colder and usually drier air currents reach the state relatively often (GIMENO et al., 2016). These invasions form frontal systems that prevent the circulation of trade winds from the eastern quadrant, causing often intense and widespread precipitations.

Therefore, unlike other southern states, Santa Catarina maintains conditions of high atmospheric humidity throughout its territory during the whole year, except for rare invasions of cold and dry air currents from southwest. This influences the vegetation, since the forest coverage ratio (including the FOM) of the Southeastern portion of South America tends to increase with rainfall, as stated by Bernardi et al. (2016).

According to Golfari et al. (1978), the araucaria does not tolerate drought conditions, and even though it develops in regions with frequent frosts, the araucaria does not require the occurrence of frosts. The same study found that the regions with araucaria recorded regular precipitations ranging between 1,250 and 2,000 mm without a dry period in the winter. In addition, the authors established that, within the region with araucaria, the lowest rainfall rate was observed in the city of Bom Jardim da Serra (1,419 $\mathrm{mm} /$ year), while the highest belonged to the city of Ponte Serrada (2,222 mm/year), both values close to the estimated thresholds.

\section{Climatic differentiation of areas with araucaria in the state of Santa Catarina}

In the state of Santa Catarina, the areas climatically suitable for Araucaria forests were divided into groups A1 and A2, in the Western portion of Serra Geral (at the center of the state's Southern Plateau) and B1, in the Western portion of the Plateau. Pursuant to the Köppen classification, climate Cfb prevails in groups A1 and A2, characterized by a typical temperate climate with average monthly minimum temperatures below $18{ }^{\circ} \mathrm{C}$ in the winter (mesothermal), warm summers with average monthly maximum temperatures below $22{ }^{\circ} \mathrm{C}$ and no dry season. However, climates $\mathrm{Cfa}$ and, partially, $\mathrm{Cfb}$ prevail in group B1, characterized by a subtropical climate with average monthly minimum temperatures below $18{ }^{\circ} \mathrm{C}$ in the winter (mesothermal), hot summers with average monthly maximum temperatures above $22{ }^{\circ} \mathrm{C}$, infrequent frosts, a pattern of rainfall concentration in summer months and no dry season (MAACK, 1981).

Groups A1 and A2 are located at the same latitudes as cluster B1, but cluster B1 is found at higher longitudes in the western portion of the state and at relatively lower altitudes. Comparatively, cluster B1 is located at the higher altitudes of the upper slopes of the Uruguayan plain.

Consequently, the regions are climatically different. Clusters A1 and A2 are spread over different altitudes throughout the Southern Plateau, but the higher elevations of cluster A2 in relation to the A1 result in differences in average and absolute temperatures, occurrence of frost, rainfall, potential evapotranspiration and water availability. 


\section{CONCLUSIONS}

- In the state of Santa Catarina, the favorable areas to the development of araucaria range between Serra do Mar (Santa Catarina costal mountains) and the Western portion of the State, always at altitudes higher than 450 meters.

- The lowest temperatures registered in each season associated with higher annual rainfall rates in the winter differentiate the areas climatically suitable for the presence of araucaria. These settings are characterized by higher water availability, as shown by their markedly high precipitation rate per year and in July in relation to a lower summer rate.

- The regions favorable to the development of the araucaria were divided into two clusters and then further divided into climatically distinct clusters: two located in the Central portion of the plateau and a third one in the western portion of the state. Higher rainfall rates, higher water availability and lower altitude differentiated the Western group from the other two groups located in the Plateau.

- The two regions situated in the Plateau differ from each other in terms of rainfall, potential evapotranspiration, water availability and altitude.

- This study's results help to establish in situ conservation areas for the araucaria forest as Conservation Units. In addition, genetic conservation programs could be designed to identify the differences between the various groups' genotypes and a potential link between the geographic distribution of the species and its genetic diversity. Additional pedological studies would be very useful to determine edaphoclimatic differences.

\section{REFERENCES}

ARZOLlA, F. A. R.; IVANAUSKAS, N. M.; NALON, M. A.; PISCIOTTA, K.; L.D.; ANTUNES, A. Z.; RODRIGUES, R. R.; JOLY, C. A. Por que tombar imediatamente a Serra da Mantiqueira no Estado de São Paulo. Governo do Estado de São Paulo. BIOTA FAPESP. 2014. Disponível em: $<$ http://iflorestal.sp.gov.br/2014/05/06/porque-tombar-imediatamente-a-serra-da-mantiqueira-no-estado-desao-paulo/>. Acesso em: 15/06/2017.

BACKES, A. Condicionamento climático e distribuição geográfica de Araucaria angustifolia (Bertol.). Kuntze no Brasil - II. Pesquisas - Botânica; 49: 31-51. 1999.

BAUERMANN, S.G; BEHLING, H. Dinâmica paleovegetacional da Floresta com Araucária a partir do final do Pleistoceno: o que mostra a palinologia. In: Fonseca CR et al., editores. Floresta com Araucária: ecologia, conservação e desenvolvimento sustentável. Ribeirão Preto: Holos; p. 35-38. 2009.

BERNARDI, R. E.; HOLMGREN. M.; ARIM. M.; SCHEFFER. M. Why are forests so scarce in subtropical South America? The shaping roles of climate, fire and livestock. Forest Ecology Management. 363, 212-7. 2016.

CARPANEZZI, A.; CARVALHO, P. E. R. Zoneamento ecológico para plantios florestais do Estado de Santa Catarina. Curitiba: EMBRAPA-CNPF (EMBRAPA-CNPF. Documento 21). 103 p. 1988.

CHOU, S. C.; LYRA, A.; MOURÃO, C.; DERECZYNSKI, C.; PILOTTO, I.; GOMES, J.; BUSTAMANTE, J.; TAVARES, P.; SILVA, A.; RODRIGUES, D.; CAMPOS, D.; CHAGAS, D.; SUEIRO, D.; SIQUEIRA, G.; NOBRE, P.; MARENGO, J. Evaluation of the Eta Simulation Nested in Three Global Climate Change Models. American Journal of Climate Change. v.3, p. 438-454. 2014.

FRITZSONS, E.; MANTOVANI, L. E.; WREGE, M. S. Relação entre altitude e temperatura: uma contribuição ao zoneamento climático no estado de Santa Catarina, Brasil. Revista Brasileira de Climatologia, [S.1.], v. 18, out. 2016.

GIMENO, L.; DOMINGUEZ, F.; NIETO, R.; TRIGO, R.; DRUMOND, A.; REASON, C.J.; TASCHETTO, A.S.; RAMOS, A.M.; KUMAR, R.; MARENGO, J. Major mechanisms of atmospheric moisture transport and their roles in extreme precipitation events. Annual Review Environmental Res. 41:3.1-3.25. 2016.

GOLFARI, L.; CASER, R. L.; MOURA, V. P. G. Zoneamento ecológico esquemático para reflorestamento no Brasil. Belo Horizonte: PRODEPEF, PNUD/ FAO/IBDF/BRA-45. (Série Técnica, 11). 1978.

GRIMM, A.; TEDESCHI, R.G. ENSO and extreme rainfall events in South America. Journal of Climatology, 22 (7): 1589-1609. 2009.

HAIR, JR., J. F.; BLACK, W.C.; BABIN, B.J.; ANDRESENA, R.E.; TATHAN, R.L. Análise multivariada de dados. 6. ed. Porto Alegre: Bookman, 2009. 688 p. 
KLEIN, R. M. Árvores nativas da Floresta Subtropical do Alto Uruguai. Sellowia, Itajaí, n. 24, p. 9-62, 1972.

MAACK, R. Geografia física do Estado do Paraná. Rio de Janeiro: Livraria José Olympio Ed, 1981, 442 p.

MARTINELLI, G.; MORAES, M. A. Livro vermelho da Flora Brasileira. Rio de Janeiro: Instituto de Pesquiso Jardim Botânico do Rio de Janeiro, 1 ed. 2013, 1100 p.

MEDEIROS, J. D., SAVI, M.; BRITO, B. F. A. Seleção de áreas para criação de Unidades de Conservação na Floresta Ombrófila Mista. Biotemas, 18: 33-50. 2005.

NAVAS, C. A.; CRUZ-NETO, A. Se extinções associadas a mudanças climáticas globais são eventos naturais, por que devemos nos preocupar com o cenário atual? Revista de Biologia, v. 1, p. 9-11, 2008.

PANDOLFO, C.; BRAGA, H. J.; SILVA JÚNIOR, V. P.; MASSIGNAN, A. M.; PEREIRA, E. S. THOMÉ, V. M. R. Atlas climatológico digital do Estado de Santa Catarina. Epagri. Florianópolis. CD-Rom. 2002.

PUCHALSKI, A.; MANTOVANI, M.; REIS, M. S. dos. Variações em populações naturais de Araucaria angustifolia (Bert.) O. Kuntze associada a condições edafoclimáticas. Scientia Forestalis, v. 70, p.137-148, 2006.

RIBEIRO, M.C.; METZGER, J.P.; MARTENSEN, A.C.; PONZONI, F.J.; HIROTA, M.M. The Brazilian Atlantic Forest: How much is left, and how is the remaining forest distributed? Implications for conservation. Biological Conservation, 142:1141-1153. 2009.

RODERJAN, C.N.; GALVÃO, F., KUNIOSHI, Y.S.; HATSCHBACH, G.G. As unidades fitogeográficas do Estado do Paraná, Brasil. Ciência e Ambiente, vol 24. p. 75-92. 2002.

VAREJÃO-SILVA, M. A. Meteorologia e Climatologia, Versão Digital 2, Recife, 2006. Disponível em: http://www.leb.esalq.usp.br/aulas/lce5702/Meteorologia_e_Climatologia_VD2_Mar_2006.pdf. Acesso em $01 / 03 / 2018$.

ZANON, M. L. B.; FINGE C. A. G. Relação de Variáveis Meteorológicas com o crescimento das árvores de Araucaria angustifolia (Bertol.). Kuntze em povoamentos implantados. Ciência Florestal, Santa Maria, v. 20, n. 3, p. 467-476 jul.-set., 2010.

WREGE, M. S.; STEINMETZ, S.; REISSER JR, C.; ALMEIDA, I. R. Atlas Climático da Região Sul do Brasil: Estados do Paraná, Santa Catarina e Rio Grande do Sul. Pelotas: Embrapa Clima Temperado; Colombo: Embrapa Florestas. 2011. $336 \mathrm{p}$

WREGE, M. S.; SOUSA, V. A.; FRITZSONS, E.; SOARES, M. T. S.; AGUIAR, A. V. Predicting Current and Future geographical distribution of Araucaria niche modeling. Environmental and Ecology Research, v. 4, p. 269-279, 2016.

FLORESTA, Curitiba, PR, v. 48, n. 4, p. 503-512, out/dez. 2018

Fritzsons. E. et.al.

ISSN eletrônico 1982-4688

DOI: $10.5380 /$ rf.v48i4.53272 
